\title{
Electron microscopic changes associated with water absorption in the jejunum
}

\author{
A. WYNN WILLIAMS \\ From the Department of Pathology, University of Edinburgh Medical School
}

EDITORIAL SYNOPSIS With the electron microscope, mucosal changes induced by the instillation of water into a segment of jejunum of rats were observed. The animals had been deprived of food and water for 24 hours.

The small intestine has the function of absorbing ingested food, water, and electrolytes. The villous epithelium, which contains abundant enzymes, performs absorptive work. Electron microscopy has demonstrated that the free surface of the cells is covered by microvilli and that adjacent cells are interlocked by folds of their plasma membranes. Absorbed substances must cross the continuous membrane of the microvilli, traverse the cytoplasm of the cell, and then leave the cell across the plasma membrane. This pathway has been demonstrated in the case of fat absorption (Palay and Karlin, 1956, 1959) and there are also electron microscopic studies on the absorption of protein and colloidal materials by a process of pinocytosis (Clark, 1959). During the course of investigations concerned with the effect of various solutions on the ultrastructure of the small intestine, changes were noted on electron microscopy, which are now reported because of their importance and interest.

\section{METHODS}

Four groups of four adult Wistar rats were employed in the experiments. They were kept without food and water for $\mathbf{4 8}$ hours then anaesthetized with ether. The abdomen was opened and a segment of mid-jejunum, about $2 \mathrm{~cm}$. long, was isolated between two light clamps, the mesenteric blood supply being untouched, and the lumen filled, but not overdistended, with distilled water by means of a tuberculin syringe and hypodermic needle. In the first group, the animals were killed after one hour, in the second after 10 minutes, in the third after three minutes, and in the fourth after 10 seconds. In all animals mucosal tissue from the segment was placed in Dalton's osmium tetroxide fixative for one hour, dehydrated with ethanol, and embedded in araldite. Sections were cut on a Servall Porter-Blum microtome, using a glass knife. Ultrathin sections were stained with $1 \%$ potassium permanganate and examined in a Metropolitan Vickers EM-6 electron microscope.
RESULTS

ONE HOUR AFTER ADMINISTRATION OF WATER In the superficial part of the epithelial covering of the villus, the cells are in close apposition, the brush border is composed of uniform microvilli, and the mitochondria are fairly dense, predominantly oval or elongated structures. The endoplasmic reticulum is clearly visible and so are the lateral cell membranes (Fig. 1). These are characteristic features of resting cells. On the other hand, the lower portions of the epithelial cells are widely separated by large spaces in which lymphocytes may be seen (Figs. 2 and 3 ).

TEN MINUTES AFTER ADMINISTRATION OF WATER A constant finding is the presence of moderately large intercellular spaces in the epithelial layer, most noticeable about the middle of the lateral cell boundaries (Fig. 4). The larger spaces seen after one hour are not visible.

Most epithelial cells show the characters of the resting phase but striking changes are present in others, either isolated cells, or, in some instances, two or three neighbouring cells (Figs. 5, 6, and 7); there is irregularity in the size and alignment of the microvilli and marked swelling of the mitochondria; the latter are far less dense than normal; in addition, small vesicles are seen. The terminal web is indistinct and beneath the brush border lies a broad zone containing occasional vesicles or electron-dense bodies.

THREE MINUTES AFTER ADMINISTRATION OF WATER The appearances are arresting (Fig. 8): the brush border shows no abnormality and the terminal web and terminal bars are clearly seen as normal structures. Most of the tissue, however, appears as a collection of very large spaces, interrupted by attenuated portions of cells. The spaces consist largely, if 


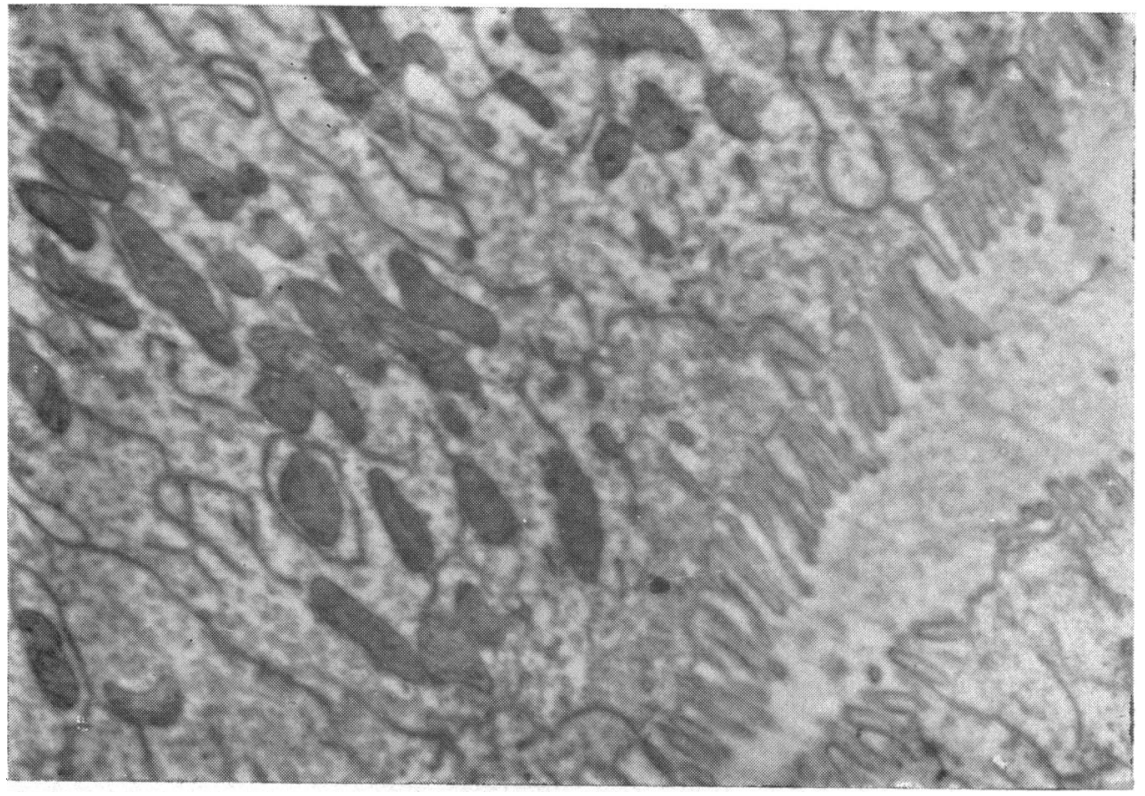

FIG. 1. Superficial part of villous epithelial cells one hour after giving water. The closely apposed cells have a brush border, endoplasmic reticulum, and mitochondria which are clearly seen. $\times 13,000$.

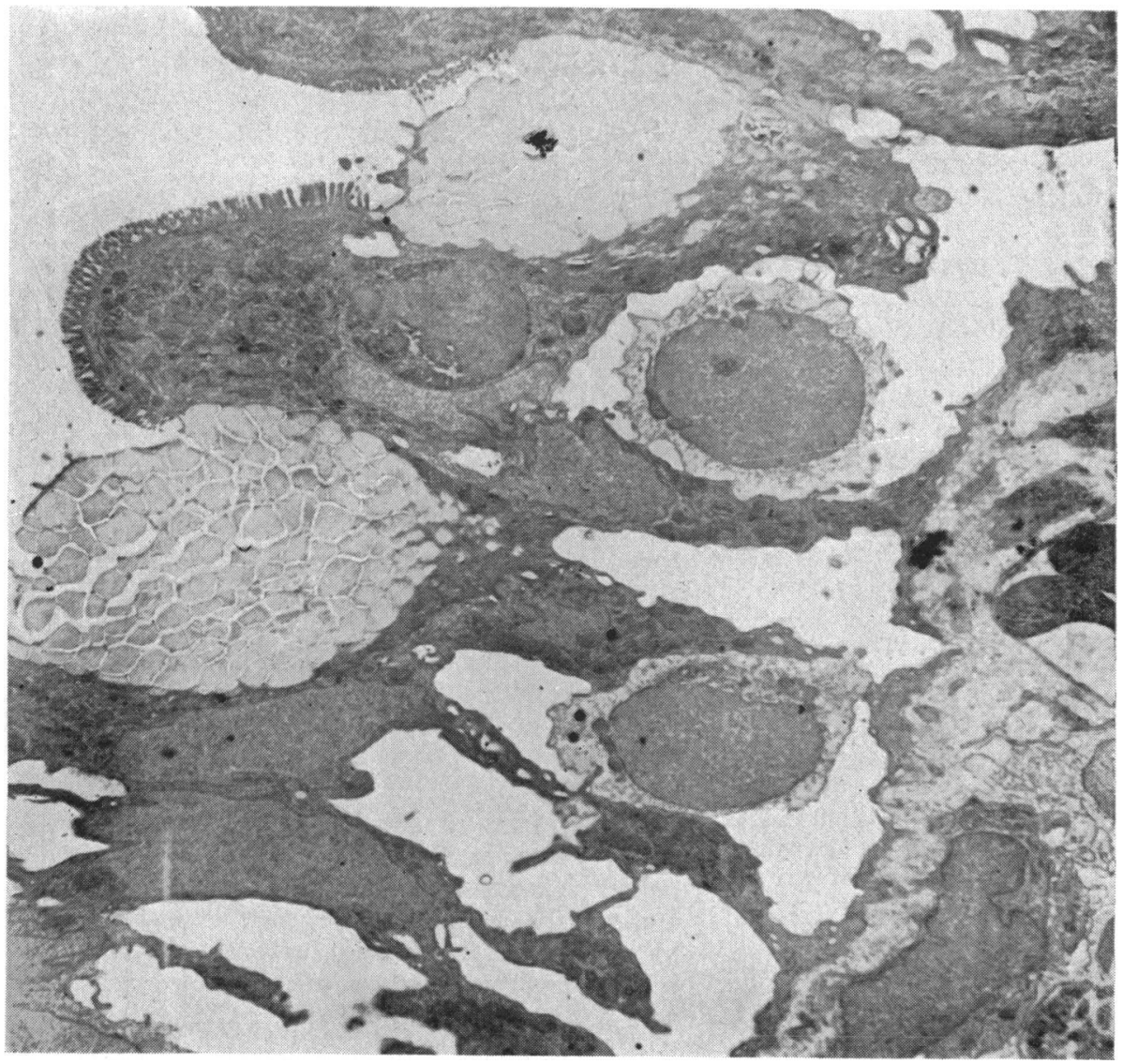

FIG. 2. Part of $a$ villus one hour after the administration of water. The lower portions of the epithelial cells, which include two goblet cells, are separated by spaces in which two lymphocytes are seen. $\times 2,500$. 


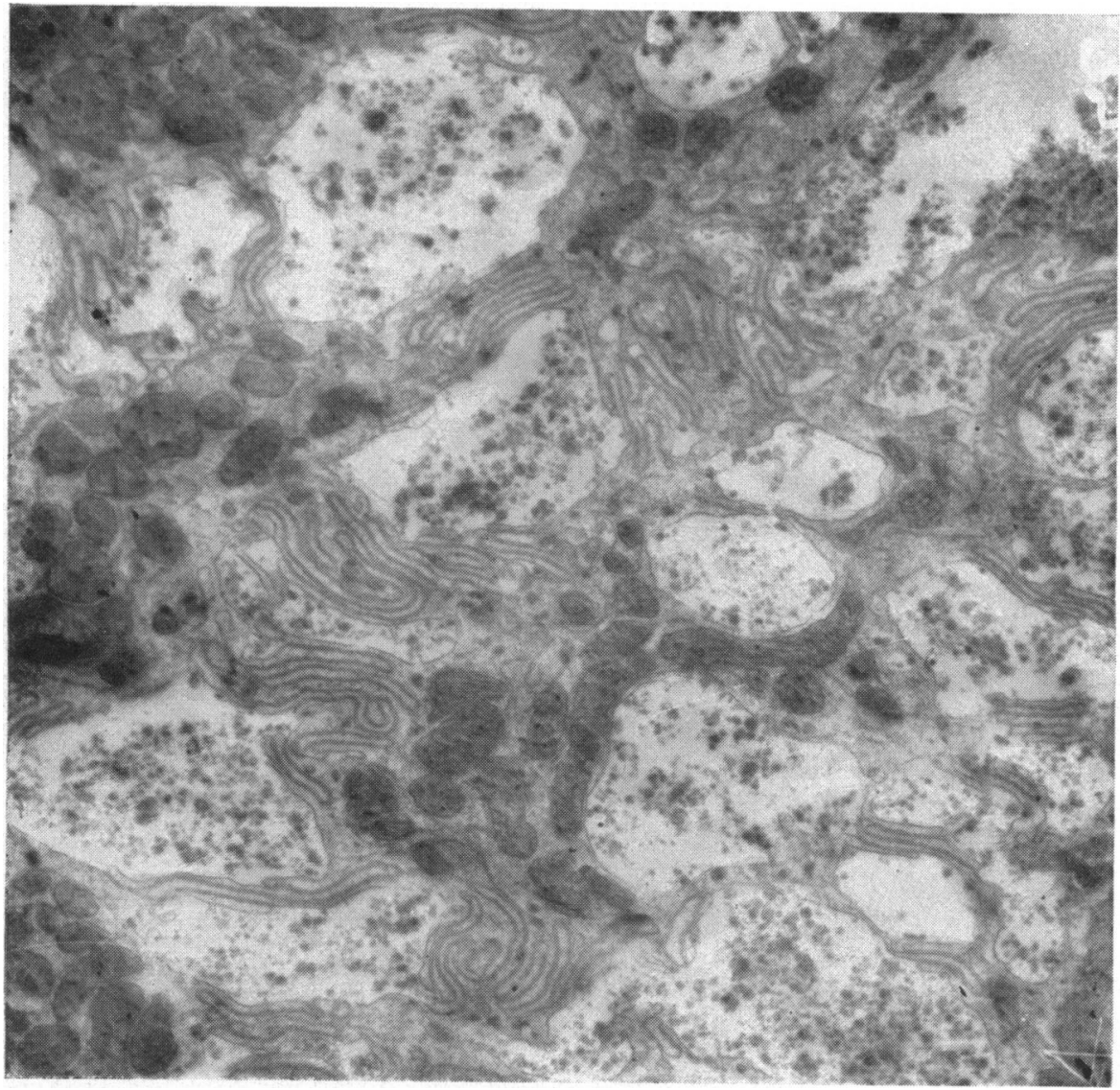

FIG. 3. Transverse section of part of a villus one hour after giving water.

Prominent spaces separate the attenuated lower portions of epithelial cells. $\times 8,000$.

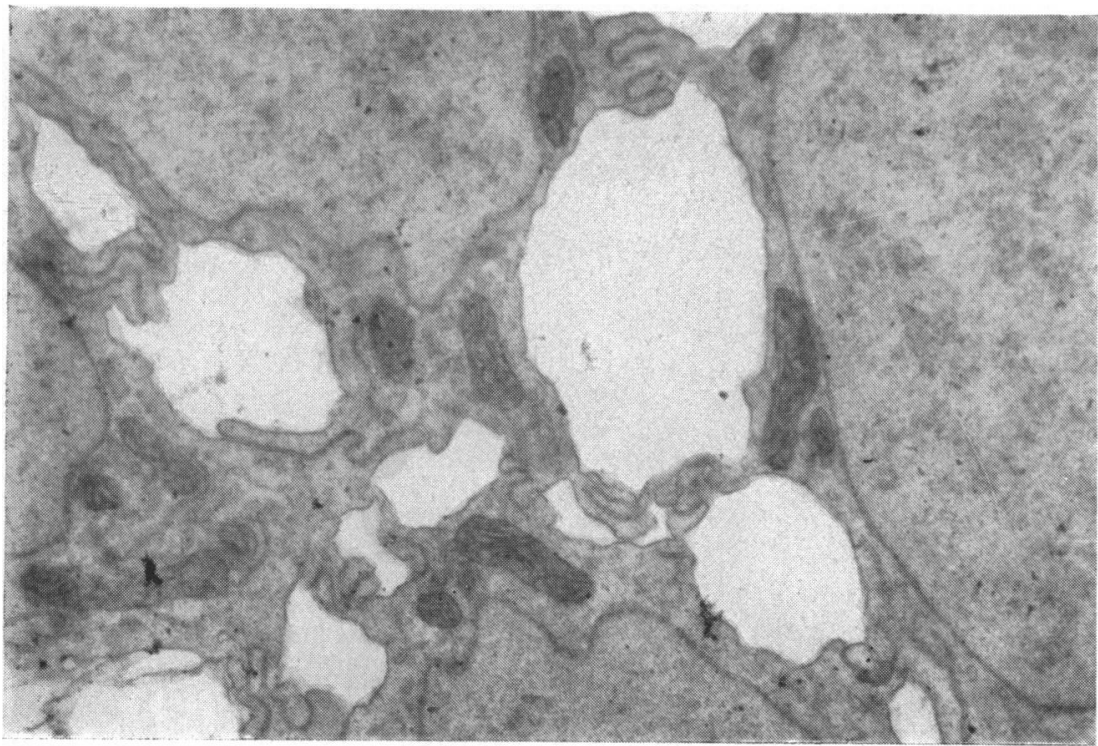

FIG. 4. Portion of villous epithelium 10 minutes after water had been administered. A longitudinal section showing the appearance of intercellular spaces. $\times 10,000$. 


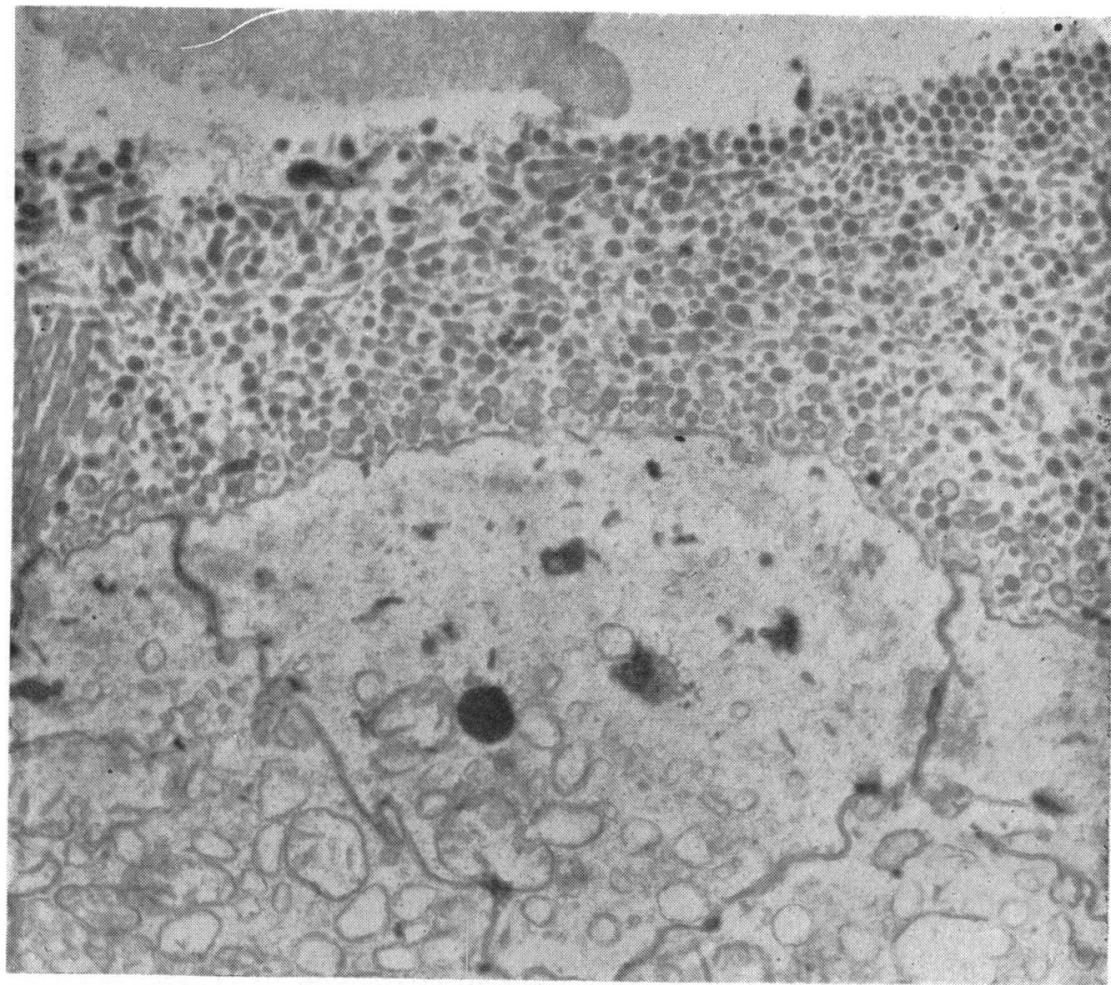

FIG. 5. Superficial part of villous epithelial cells 10 minutes after water had been given, showing irregular microvilli and swollen mitochondria.

$\times 10,000$.

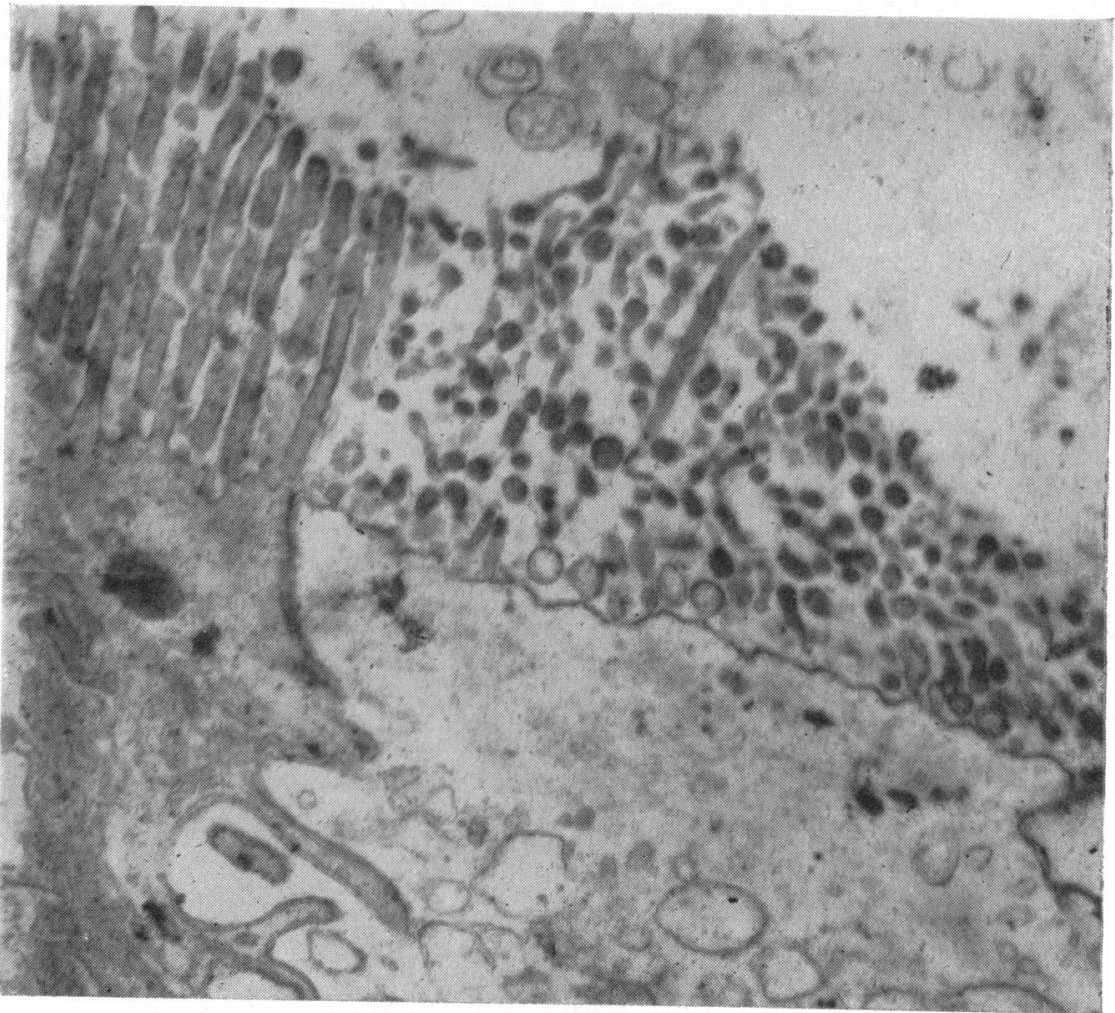

FIG. 6. Portions of two adjacent epithelial cells from a rat given water 10 minutes earlier, showing a striking contrast in the appearances. $\times 16,000$ 


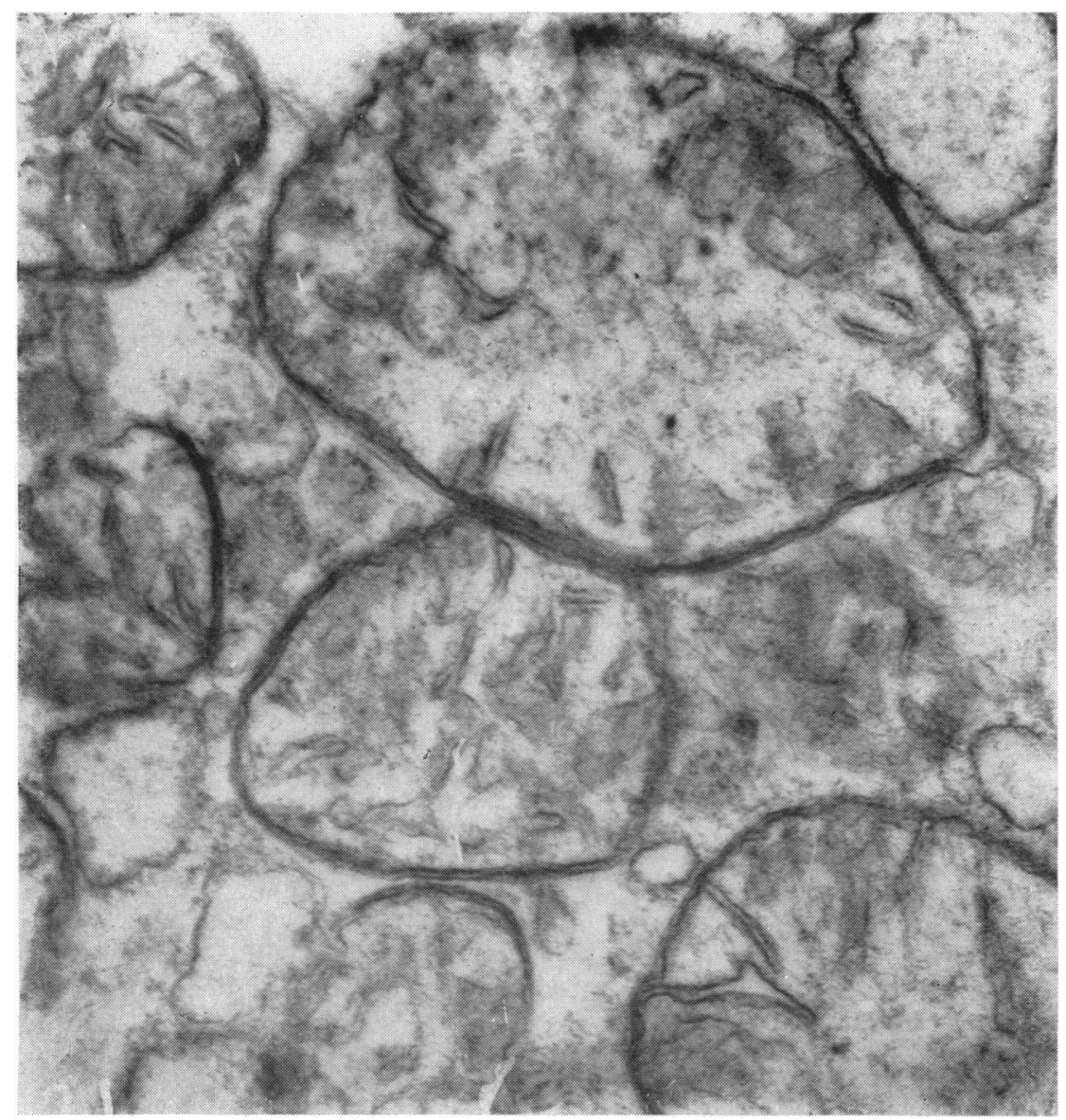

FIG. 7. Swollen

mitochondria. $\times 40,000$.

not entirely, of enormously distended intercellular spaces.

TEN SECONDS AFTER ADMINISTRATION OF WATER Changes similar to those just described are seen but are less conspicuous (Fig. 9).

\section{DISCUSSION}

The manner in which many materials are transferred across the epithelial boundary of the gut is gradually being understood, particularly since the introduction of isolated intestinal segments as a method for studies in vitro and also by the use of isotopes. Much, however, remains unexplained. Since Heidenhain (1894) formulated the concept of an active participation of the intestinal mucosa in water absorption from the intestine, evidence has been adduced for and against this theory. In isolated segments of rat small intestine, water movement was found to be passive following the osmotic forces set up by net solute transport (Curran, 1960; Clarkston and Rothstein, 1960). On the other hand, experiments in vivo with Thiry-Vella loops in dogs (Vaughan, 1960) and in cats (Ullmann, Dikstein, Bergmann, and Birnbaum, 1960) demonstrated that water movement occurs in the absence of, or against, high osmotic gradients, suggesting an active transport mechanism. These differences may be accounted for by the techniques used and the increased permeability of isolated gut segments. Even in isolated preparations, however, Fisher (1954, 1955) and Smyth and Taylor (1957) showed that water transport was dependent on the presence of glucose and relatively independent of hydrostatic and osmotic forces.

Whatever can be said for or against active and passive theories, electron microscopy has now revealed changes pointing to the rapid movement of water from the free surface of the cell to the lateral intercellular spaces; the latter become enormously distended within a few minutes. This movement is compatible with the concept of cell boundaries being 


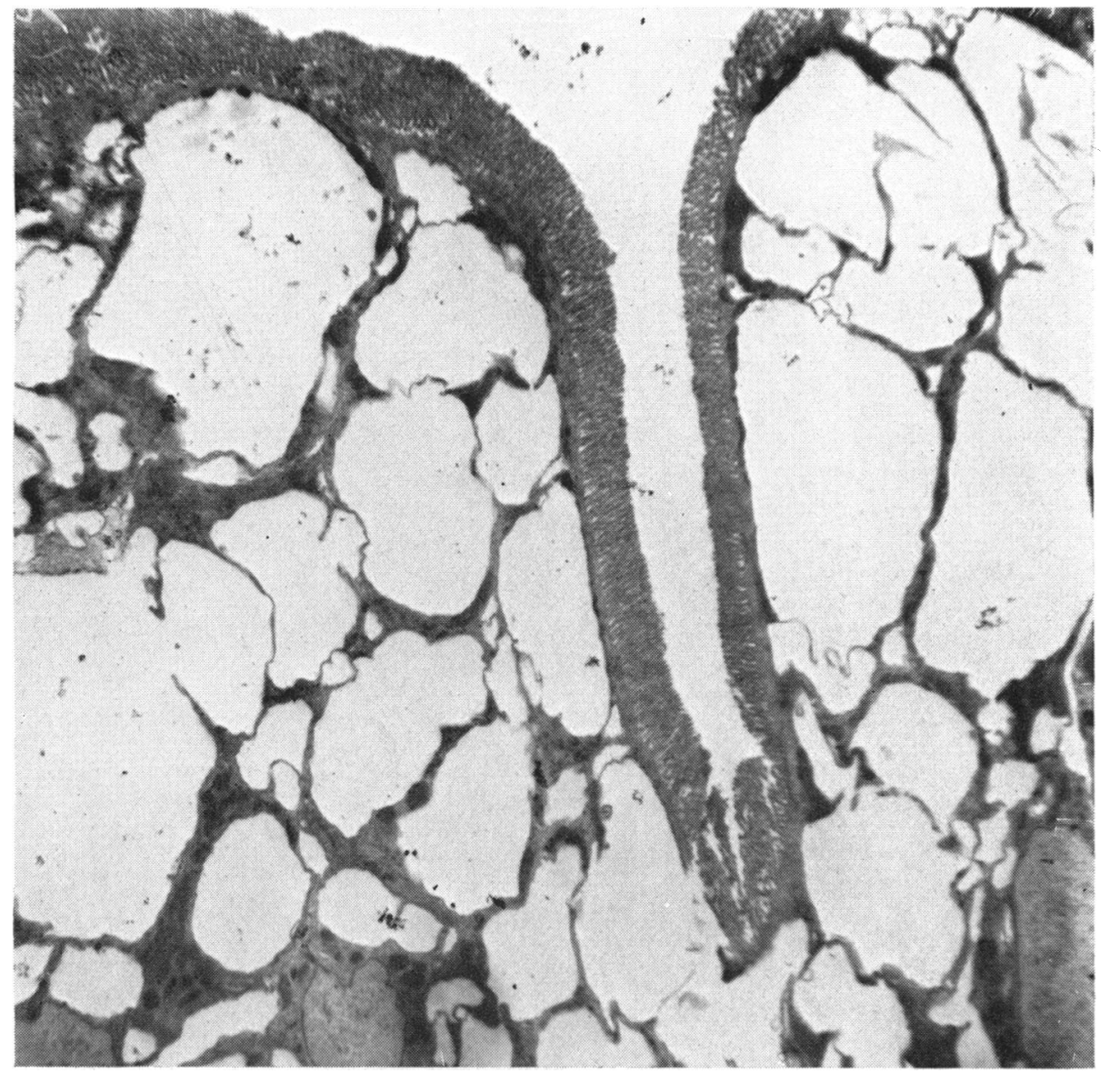

FIG. 8. Superficial portion of intestinal villus from a rat given water three minutes earlier.

There is very marked distension of intercellular spaces. $\times 1,500$. 
actively metabolic and containing ion-binding radicles. Moreover, under the experimental conditions reported here, there was no dependence on the presence of glucose: the fluid instilled into the lumen of the bowel consisted of distilled water only.

Cloudy swelling or hydropic change is an early and often reversible indication of cellular damage which occurs after interference with cell metabolism by many causes, such as anaerobiosis, low temperature, or poisoning by organic chemicals or heavy metals (Cameron and Spector, 1961). It is a change almost invariably accompanied by an outflow of potassium from cells. Harris (1957) has shown that if the cell resembled a model in which a restrictive membrane enclosed a space in which potassium ions moved freely, then for a cell of $80 \mu$ diameter, equilibration of intra- and extra-cellular potassium should be $90 \%$ complete in less than one second. In fact, mixing occurs much more slowly (Cameron and Spector, 1961) and in this respect, it is of interest that the ultrastructural changes were more marked after three minutes than after a few seconds.

Mitochondria isolated from cells in cloudy swelling have been found to be swollen and laden with water, and it has been suggested that some of the vacuolization seen in the cell cytoplasm by light microscopy in this condition in fact represents such swollen mitochondria (Cameron and Spector, 1961). It is, therefore, of considerable interest that in the experiments in vivo reported here swollen mitochondria were observed in some of the epithelial cells 10 minutes after the instillation of water into the lumen of the bowel. These same cells also showed changes in the size and alignment of the microvilli. The latter are structures ordinarily of remarkably constant appearance and, in the small intestinal epithelium have been noted as irregular only in primary sprue (Hartman, Butterworth, Hartman Crosby, and Shirai, 1960; Zetterqvist and Hendrix 1960; Shiner and Birbeck, 1961; Shearman, Girdwood, Wynn Williams, and Delamore, 1962), and in response to the administration of 4-aminopteroylglutamic acid (Aminopterin) to rats (Wynn Williams, 1961).

I am most grateful to Professor G. L. Montgomery for his interest and help, to Mr. T. C. Dodds, and Mr. George Wilson for technical assistance, also to the Advisory Committee for Medical Research and the Secretary of State for Scotland for generous financial assistance in this work.

\section{REFERENCES}

Cameron, Sir Gordon Roy, and Spector, W. G. (1961). The Chemistry of the Injured Cell, pp. 5-12. Thomas, Springfield, Illinois.

Clark, S. J. Jr. (1959). The ingestion of proteins and colloidal materials by columnar absorptive cells of the small intestine in suckling rats or mice. J. biophys. biochem. Cytol., 5, 41-50.

Clarkston, T. W., and Rothstein, A. (1960). Transport of monovalent cations by the isolated small intestine of the rat. Amer. $J$. Physiol. (Washington), 199, 897-906.

Curran, P. F. (1960). Na, Cl, and water transport by rat ileum in vitro. J. gen. Physiol., 43, 1137-1148.

Fisher, R. B. (1954). The absorption of water and some nonelectrolytes from the surviving small intestine of the rat. $J$. Physiol (London), 124, 21-22p.

- (1955). The absorption of water and of some small solute molecules from the isolated small intestine of the rat. Ibid., $130,655-664$

Harris, E. J. (1957). Permeation and diffusion of $\mathrm{K}$ ions in frog muscle. J. gen. Physiol., 41, 169-195.

Hartman, R. S., Butterworth, C. E. Jr., Hartman, R. E., Crosby, W. H., and Shirai, A. (1960). An electron microscope investigation of the jejunal epithelium in sprue. Gastroenterology, 38, 506-516.

Heidenhain, R. (1894). Neue Versueche über Aufsaugung in Dünndarm. Pfügers Arch. ges. Physiol., 56, 579-631.

Palay, S. L., and Karlin, L. (1956). Absorption of fat by jejunal epithelium in the rat. Anat. Rec., 124, 343.

- and Karlin, L. J. (1959). An electron microscope study of the intestinal villus. II. The pathway of fat absorption. J. biophys. biochem. Cytol., 5, 373-383.

Shearman, D. J. C., Girdwood, R. H., Wynn Williams, A., and Delamore, I. W. (1962). A study with the electron microscope of the jejunal epithelium in primary malabsorptive disease. Gut, 3, 16-25.

Shiner, M., and Birbeck, M. S. C. (1961). The microvilli of the small intestinal surface epithelium in coeliac disease and in idiopathic steatorrhoea. Ibid., 2, 277-284.

Smyth, D. H., and Taylor, C. B. (1957). Transfer of water and solutes by an in vitro intestinal preparation. J. Physiol. (London), 136, 632-648.

Ullmann, T D., Dikstein, S., Bergmann, F., and Birnbaum, D. (1960). Absorption of iso-, hypo- and hypertonic solutions from small intestine of cats. Amer. $J$ Physiol., 198, 1319-1322.

Vaughan, B. E. (1960). Intestinal electrolyte absorption by parallel determination of unidirectional sodium and water transfers. Ibid., 198, 1235-1244.

Wynn Williams, A. (1961). Light- and electron microscopic studies of the effects of 4-aminopteroylglutamic acid (Aminopterin) on the mucous membrane of the small intestine of the rat. Gut, 2 , 346-351.

Zetterqvist, H., and Hendrix, T. R. (1960). A preliminary note on an ultrastructural abnormality of the intestinal epithelium in adult celiac disease (non-tropical sprue) which is reversed by a gluten free diet. Bull. Johns Hopk. Hosp., 106, 240-249. 